\title{
Talking Strategies and Speech Functions
}

\author{
Vilmos Keszeg \\ Department of Hungarian Ethnography and Anthropology, Babeş-Bolyai University, Cluj-Napoca
}

\begin{abstract}
The article sets forth two different methodological models. The first one follows the accepted patterns and rules of speaking. According to this, the aims, attitudes, and motivations of the participating actors, as well as the thematic implications and external, factual references of the topic become evident during the speech event. These observations explain why and how experiences are elaborated, shared, and transmitted. This model of speaking culture was established by Dell Hymes (ethnography of speaking). In the second kind of speech situation, the researcher observes the communication between individuals who do not know each other and investigates the self-representational aims and strategies of the speakers. This model follows ethnomethodological points (E. Goffman).
\end{abstract}

Keywords: popular literacy, narratology, life histories, popular beliefs

\section{INTRODUCTION}

I was introduced to the literature on the ethnography of speaking in the 1970s. Hermeneutics, communication theory, structuralism, and semiotics all popped up at the same time in my milieu at the University of Cluj-Napoca. Knowing of Dell Hymes was not mandatory; for me, however, it was a new, thought-provoking read. This experience accompanied me on my field trips. In the years to come, when opportunities for professional discussions emerged, it was more convenient and more advantageous to follow the ideas of Mircea Eliade or Claude Lévi-Strauss. Over the past decades, I have conducted much research and subsequently carried out many analyses, given many lectures. And although I never spoke of it, I always had a feeling that there was something missing. I was always amazed that readers and students did not sense this lack. Because something has always remained unspoken. When someone speaks, why do they speak instead of remaining silent? When someone speaks, when do they stop? When someone speaks, what do they say and how? What does what they say mean? And if someone speaks, who is it that responds and how? And what else are they thinking of besides what they just said? I believe that after many years of collecting data, I've learned to interpret 
the talking man. Whether I was in the field or on the street, on the bus, in the barber shop, the communication happening around me claimed my attention.

When I realized why these questions were of interest to me, I became convinced that folkloristic research had lost momentum. When Miklós Révai issued the first call for Hungarian-language folklore collections in 1782, and when György Gaal, János Mailáth, and later Arnold Ipolyi, János Kriza and contemporaries began recording folk poetry, they certainly did not expect that those who followed in their footsteps over the next century would not move beyond their initial collection approach. The birth of folkloristics and, more broadly, ethnology was closely linked with the discovery of society. Birth registrations and censuses led to the rise of statistics and other social sciences, and at the same time to the recognition of social segmentation. Interest in the specific culture of other strata and groups also emerged at this time, as did the exploration and canonization of folk poetry. I also realized that in the early $20^{\text {th }}$ century - when folk poetry was still vivid and abundant, in an age when collectivization brought on the suppression of folk poetry and forced it to be practiced under organized circumstances, when traditional topics were being supplanted by life stories and life experiences and the techniques and mediums of communication diversified - the approach of research has not changed: researchers were only interested in issues of content, typology, and genre. And when, thanks to some antecedents, folk poetry was staged in the 1970s and was then utilized in nursery and elementary schools after 1990, most of the time they only cared for tracing and revitalizing the sujet, the linguistic and acoustic registers.

When the paradigm shift that took place in linguistics in the 1920s turned the attention to speaking, not just language, folkloristics did not respond to the challenge, though it easily could have. And it was unable to keep up even when the science of communication became independent from linguistics. It would only have been necessary to recapitulate the notes that were already available in regard to the spoken word, and to widen the horizon of interest in current research.

Over the past decades, my research has been primarily based on conversations. The collecting situation is a speech situation in which interpersonal and intercultural communication takes place. The collector usually comes from science, initiates the conversation, and asks questions based on the logic and current interests of science. These questions relate to a partly known, partly unknown culture: to its content, its role in the life and cultural practice of a community and an individual; to the individual's attitude toward the element of culture being studied; to his/her embeddedness in the culture and in the application of the element of culture being studied. In turn, the person being interviewed asks about the researcher, the motivations of his/her interest, and the uses of the conversation's outcome. That is, in a collecting situation, both parties must ask questions, and both must answer the questions.

As with any speech situation, the following rules apply to the collecting situation as well. 1. Communication follows the principle of reducing uncertainty. At the beginning of the communication event, the interlocutors do not have a firm idea of each other's opinions on the subject. During the conversation, this uncertainty gradually decreases, and by the end of the communication event, the position of the other party becomes clear to them and, depending on the subject, they come to a common position or accept 
their differences of opinion. ${ }^{1} 2$. The dialectic of close relationships (being cooped up for the duration of collecting) is based on a simultaneous push-and-pull force, that is, on opposition, basically. Contents that emerge in the process of the conversation encourage the interlocutors to continuously elaborate, reconsider, modify, and defend their position. Every individual with whom the collector converses is embedded in the examined culture differently, not only carrying and transmitting but also altering and abandoning the tradition, and not only knowing/not knowing it but also personally interacting with it. At the same time, the perception of the differences in knowledge and opinion of the interlocutors will activate speaking strategies on both sides. These include wonderment, enthusiasm, questioning, elaboration, requesting exemplification, contradiction, disputing the claim, reasoning (and requesting it), falling silent, unexplained insinuation, and distortion. ${ }^{2}$ 3. During the conversation, the participants accept and apply the principle of responsibility: they closely follow the speaker and effectively influence the course of the conversation with their responses. The basis for this process is the common platform upon which they establish the interpretation of the subject (CLARK - CARLSON 1982). The principle of cooperation delimits their contribution to the conversation: they shall be subject to the purpose or direction of the conversation. Their contribution can be analyzed in terms of quantity, quality, relevance, and demeanor (GRICE 1975).

Aside from these general features, a collecting situation is always particular, i.e., the collection event is always unique.

\section{THE GOALS AND LESSONS OF TOPIC-ORIENTED RESEARCH}

I started collecting belief narratives in the mid-1970s, when I was a high school student. As a disciplined student, at school I learned and respected materialistic views, and as a child of a religious family, in church I learned religious views. I experienced the fact that people believed in other things besides science and religion in my surroundings in the Mezőség, as well as in the collecting camp in Háromszék where I spent two weeks as an eighth-grader. In the first years I collected curiosities. As a child, I learned of the storm-controlling garabonciás, of the old women casting hexes, how the women visiting a newborn leave it with a dream, what the mother who is forced to fetch water in the puerperal period needs to do to ensure that the well does not get contaminated - the remaining fragments of a former mentality. When I collected enough elements, I managed to create a unit. I arrived at this point at the end of my university studies. Meanwhile, I came across Lévi-Strauss' structural approach and Éva Pócs' Folk Beliefs in Zagyvarékas (Pócs 1981). Readings like these led me to state in my dissertation, about a world that was close to me, that belief was a system, a different perception, interpretation, and display of the world through logic and language. After university, I was alone in my country house with the beliefs of the Hungarian people (DöмÖтöR 1981), and with Zoltán Fejős' collection from Karancskeszi (FEJöS 1985). I taught literature for nine years, partly with the knowledge of folk poetry that I was taught at

\footnotetext{
${ }^{1}$ Charles Berger's theory $(1975,1988)$ is recapitulated in GRIFFIN 2001:138-149.

${ }^{2}$ Leslie Baxter and Barbara Montgomery's theory $(1992,1996)$ is recapitulated in GRIFFIN 2001:168180.
} 
university for a year - that it is traditional, communal, anonymous, and an art. I regularly collected, unobtrusively. Since the securitate quickly set its sights on me because of my educational activities, I had to go into the field unnoticed. To places that I frequented anyway and where I was in sight, that is to say, to my own village and its surroundings, and to far-off farms where I could vanish. In those years, I talked to only a few people, but I talked often and much. Sometimes I would have conversations with families, neighbors, and sometimes I would talk for hours with a single person. The same event would be recounted by different people in newer and newer contexts, or several people would recount the same event. Personally, or through these accounts, I got to know the parents, grandparents, grandchildren, neighbors, all those who were the actors, sources, or knowers of the stories. I knew what happened to whom and when: who was beset with injury, hex or illness, who had encountered the devil or an unclean person, who had seen a wraith or a dragon snake, was possessed, or healed someone.

At that time, I had to formulate for myself what I wanted to learn in the course of these collections, and I decided that it was the use of belief, the development of belief awareness, its functions, and its changes.

\section{SITUATIONS, MOTIVATIONS AND FUNCTIONS OF TALKING ABOUT BELIEF}

Belief narratives are therefore one of those permanent speech situations that have been continuously addressed even before I came on the scene. When someone got sick, the search for causes and signs and healing opportunities began. When the relationship between a mother-in-law and a daughter-in-law or between two neighbors deteriorated, when somebody was harmed, the accusations, the allegations began. The first condition for solving a crisis is the narrative presentation of the situation: the causes, the circumstances, the collection of episodes, the filling of gaps, the construction of the narrative representation, its circulation, and the confrontation of interpretations. Talking about belief resembles an underground stream: in places it hides, in others it reveals itself, in places it breaks into branches and the branches flow in different channels, then they become swamps or merge into bigger streams. ${ }^{3}$

This is when I realized that what to me is collecting, to my informants, it is a natural speech situation. What they told me, they told me not just because I asked about it, but because they were in the habit of talking about it. Listening and inquiring, falling

\footnotetext{
${ }^{3}$ The perception of reality, the narration and interpretation of a perceived reality, and the distribution of the narrative representation can be expressed with three types of stories: the story that has been experienced, the story that has been told, and the untold story. The typology of W. Barnett Pearce and Vernon E. Cronen is described in GRIFFIN 2001:65-71. The story that has been experienced is the experience and interpretation of reality within an event, the discovery of contexts, and the realization of the individual's place in the event and the context. The story that has been told assigns the story that has been experienced an actual communicative intent: indignation, complaint, accusation, wonder, relevance. Storytelling is an illocutionary act, and the text is a performative utterance, considering that it often changes the relationship between people, between people and objects, between man and the environment. For research, the biggest challenge is studying the untold story. Examining the withheld content, the reason for the withholding and other circumstances requires a special attention.
} 
silent and talking are part of everyday life (and within that, of continuous discourse), and are means of engaging with society just as maintaining workplace relationships is. ${ }^{4}$ Let us take a look at the functions of talking about belief: an episode of family history, an episode of the life history of a person (neighbor, acquaintance, fellow soldier), an autobiographical episode, a story related to an object or a place, the story of a dream, illness, suffering, or travel, a transcendental experience, an event that took place in a past world or in another world (neighboring village, city) - that is, a narrative tradition. These are all functions that keep the stories on the agenda whenever they become relevant. When they talk about the dead at the wake, when someone suddenly falls ill, when the neighbors start talking. When collecting, I also always asked the person sitting across from me to tell me where, when, and from whom s/he heard the story s/he just told me and with whom, why, and under what circumstances s/he had discussed it.

And what motivates the conversation? Narrating an event can be motivated by its depressing nature, by the pain one suffered, by fear, compassion for the sufferer, gloating, wonderment over what happened, disbelief, accusation/allegation, or the validation, justification, questioning, or mocking of the verity of the event. As a result, a belief narrative can be illustrative, argumentative, explicative, or parodistic in nature; it can be uttered in a whisper, escalate into tears, end in perplexity, or incite laughter. Talking about belief can accommodate strategies like fictionalization, domestication, distancing, and approximation. In the case of fictionalization, the event is missing the situative elements of placement in space, time, and society. In the case of domestication, the story is embedded in an identifiable space, time, and human network of relationships. In the case of distancing, the speaker positions the event in the past, in the neighboring village, in the lives of unknown, unnamed people; whereas with approximation, the event takes place in one's own village, on one's street, in the recent past, in the life of a living authority figure (parent, spouse). The tools of fictionalization, domestication, approximation, and distancing are proxemic codes that use elements related to space (life world), time, and society. ${ }^{5}$

In 2000 , I was unexpectedly offered the opportunity to understand how the repertoire of belief narratives becomes active. One of my informants informed me by phone that he was looking into water scrying because of a recent incident of theft. During the few hours of my being there, I found out that after the theft, he roamed the village and inquired from everyone who, why, how, and with what results had water scrying done recently. On the one hand, he wanted to put together a detailed script of the ceremony for himself; on the other, he warmed up the village for the upcoming event. By putting the stories of theft and water scrying into circulation, he persuaded the village that the damage to his family was actually a public affair: someone in the village had violated the norms of coexistence. The field had also served up another edifying surprise. After the ritual had ended, the adults living in the house sat down with the seven girls scrying the water, reconciled what was seen in the water, and constructed the narrative representation of the vision that could be circulated in the village. ${ }^{6}$ The village whose value system had been

\footnotetext{
${ }^{4}$ Types of social embeddedness: Granovetter 1994.

${ }^{5}$ Procedures known in folkloristics as epic laws are recapitulated in VoIGT 1978.

${ }^{6}$ This experience prompted me to redefine the interpretation of ritual based on talking strategies. KeSZEg 2002.
} 
breached was eagerly awaiting the news. When it turned out that it was a déclassé person staying in the village temporarily that had committed the theft, the village could relax. The story went around the village within hours.

In a collecting situation, the collaborative strategy used to talk about belief may be related to the personal involvement of the speaker in the belief or event ${ }^{7}$ : experienced it himselves/herselves, happened to a close relative or enemy, when and by whom it was recounted, how often it was brought up. And it was also related to the collection situation: his/her relationship with the collector, the ideas s/he has about the finality of the collection, the extent to which s/he is able to tune in to the collector's intent and habitus - the collector requests help with the research and wants to run through a presumed repertoire; simply inquiring about what happened in the visited world; how the parents of the informant had lived; is s/he curious about what s/he associates with what, how $\mathrm{s} /$ he interprets the belief event, the direction in which s/he moves the event along. What failures and grievances s/he faced, whether s/he is proud of his/her child and/ or grandchild; is s/he in disagreement with the different orientations of young people, the way of the world. What s/he is listening to on the radio, watching on TV. What the doctor said about the state of his/her health during the last consultation. And it is equally important to take into account who else is present apart from the collector and the informant, who is nearby, who might enter the room.

If the collector leads a targeted conversation, informants will also adapt to the rhythm: they will help scan motifs and episodes, shorten, typify, position the belief in their own life, in the context of the local world and interpersonal relationships. And if they feel (and it is hard to grasp why someone would travel for this from Cluj) that the researcher is truly interested in them, they let themselves enjoy the conversation: voicing their doubt, indignation, satisfaction, joy, and taking control of the conversation - bringing up topics, and inquiring about the researcher's life, work, and intentions.

If both parties have enough patience, the collection may keep moving away from and returning to a subject. During the conversation, two syncretic forces are exerted on the speakers and the text: a centripetal and a centrifugal force. The conversation keeps gravitating towards the subject. In fact, the subject is made up of implications, and it acts as a cohesive force, as long as it gathers all possible implications, everything possible the speakers have to say. When its associative horizon is complete, it is exhausted, its influence is lost, and the conversation changes direction (Keszeg 1993). Because of my impatience, I have blundered on several occasions by turning off my Dictaphone too early. These incidents taught me that those sitting across from me will answer my questions according to their own logic, often with extensive digressions and personal associations. The implications of the subject, the associations form the domain of implied meaning which those sitting across from us consider as evidence that legitimizes or delegitimizes

\footnotetext{
${ }^{7}$ Personal involvement is a sociological category. It indicates the significance of an existing problem for the individual, and the extent to which it is perceived as a problem. Muzafer Sherif distinguishes three zones of attitude: acceptance, rejection, and non-commitment. Cited in GRIFFIN 2001:185-195.
} 
the belief. If collecting fails to reveal this, the belief narrative as a collection trophy will remain a text fiction. ${ }^{8}$

I came to Magyarpalatka for the first time in 1991. Among others, I knocked on a woman's door. We talked uninterrupted for a long time in the kitchen. She was born in 1935, came of marriageable age around 1955. Her parents did not accept her suitor, either because he was poor or because he was Romanian. When she realized that her youth was passing her by, she decided to have a love child. She gave birth to the child in February, at the age of 33. Her parents resented her, the village slandered her and shut her out. She wondered how she was going to raise her child as a single mother. The problems made her sick, she became withdrawn, pessimistic, she had given up on life. Her family encouraged her to see a priest.

The priest prescribed nine weeks of fasting, two days a week. On the sixth week, her father became ill. On the Tuesday of the ninth week, her father collapsed again. On Christmas Friday, her mother has taken ill. She was ill for six weeks. The mass and the fasting had worked: it turned out that her parents were to blame for her life going wrong. She prayed a lot for her parents' recovery. At the time of our conversation, she was 55 years old, I was 20 years younger. Perhaps she had been waiting a long time for an opportunity to unfetter her soul, which she could not do with a family member or a neighbor. I proved to be suitable: I listened carefully, I was a stranger, i.e., I came and went. When she was assured of this, it was she who brought up the subject. We talked about her going to see the Romanian priest. "Well, these things are not talked about, they are family secrets. Someone might tell their husband or child... After some time, they might tell. I talk about myself, at one time I was like that, too. When I was young" - she began her story. As a courtesy, I put a chocolate on her table when I was about to leave. She insisted I accept ten eggs from her farm.

Aunt Mányi from Mezőkeszü was in her 90s when I visited her. The pastor of the village escorted me. Aunt Mányi has been bed-ridden for years, taken care of by her daughter-inlaw. The pastor had to leave, the lady of the house escorted him. Taking advantage of the situation, Aunt Mányi started talking. She was breastfeeding her firstborn daughter in the yard. Someone threw a curse through the air, and the curse fell on the baby. She lived 36 years, suffering from a serious illness. Neither doctors nor priests could help her. When her daughter-in-law returned, Aunt Mányi became withdrawn. Perhaps it was the last time she had complained about the greatest sorrow of her life.

\footnotetext{
${ }^{8}$ According to Mikhail M. Bakhtin, in the domain of implied meaning, "the speech situation penetrates into the utterance itself and becomes an essential part of its meaning" (BAKHTIN 1985:20). The meanings implied in the text are communal in nature: "this fundamentally deep social implication is completely objective: after all, it is the material embodiment of the world as reflected in the consciousness of the speakers $[. .$.$] as well as the real life conditions that create the community of$ judgment: the speaker's belonging to a family, a profession, a class, some other social group, and ultimately an era" (BAKHTIN 1985:21). "Family, gender, nation, class, day, year, era all have their own domain of implied meaning, and the more specific the common environment, the clearer the conventional meaning. The more tight-knit a community of speakers, the more economical and clearer the conversation (BAKHTIN 1985:16-23, especially 19-22). Conversely, contents assumed by the researcher are implied meanings (conversational implications) that are either inaccurate or not expected by the members of the local society (GRICE 1997:227).
} 


\section{BELIEF AND NON-BELIEF: THE CONTEXTS OF BELIEF}

The social elite's disavowal of folk traditions, the spread of the revolution of enlightenment through education, the integration of the achievements of the technological revolution (transportation, remote and mass communication, industrial technology) into everyday life, the emergence, spread, and everyday use of (mass) media, the professionalization of administration, jurisdiction, religious life, and management institutions left less and less room for beliefs. The collectible nature of beliefs and the sometimes surprisingly rich outcome of belief research proves, on the one hand, the polyphony of human thinking: that science, religion, and belief do not eradicate, but rather complement each other. ${ }^{9}$ Each system has a different function. The term 'parallel asynchrony' is really fitting, ${ }^{10}$ but not in cartographic terms; rather, it refers more to the complexity of the individual interpretation of the world, the capability for tolerance, the demand and practice of the right to personal interpretation. Continuing my previous sentence: on the other hand, we are witnessing the production of new beliefs. Science and technology themselves produce their own beliefs: assumptions, prognoses, unfulfilled promises (hopes).

However, I do not wish to continue this thought at the moment.

Time after time I realized that belief cannot be collected without other beliefs or nonbeliefs. Because a family, an individual, a settlement has different events in its history. And beliefs should not be extracted from these contexts, they should not be separated from non-beliefs, because then they are no longer authentic, no longer understandable.

My very first acquaintance was János Kocsis (1932), a man from the generation of my parents. He grew up on a farmstead and was thus illiterate. In my childhood and adolescence, he was my neighbor. On winter nights, he would come over to tell a story, looking for an audience. He was delighted by my interest. I was the last one around him that was not only willing to listen to all he had to say but encouraged him to recount his memories and experiences. Most of the time he looked for me, knowing that I would take paper and pencil upon his arrival and put a new cassette into the tape recorder. $\mathrm{He}$ related his life, all of his father's teachings. He sang, whooped, chanted. I've listened to everything he knew over the years. But it was more edifying what he said about the origins of his knowledge and his fate. In his family, there were ten children from three marriages. The parents had taught them everything they needed to know in life. They only failed to teach János Kocsis to write and read; however, his siblings also only learned to write in school. I learned from János Kocsis how knowledge is organized into a system. He knew what needed to be learned from the mother, what from the father, what a son had to learn and what a daughter had to learn. He knew all that he needed to know about the flora and fauna of the Mezöség, all the roads, paths, hills, and bushes of his habitat, and everything about winter and summer. He knew the time for everything. When he applied them, all the elements of his knowledge reminded him from whom and when he learned them. One time, during the October-November period, he refused to

\footnotetext{
${ }^{9}$ Bronislaw Malinowski discounted the magic — religion — science line of development. These forms of consciousness live in parallel because they assume different functions (MALINOWSKI 1925/1948).

${ }^{10}$ The principle of parallel asynchrony is an idea of $20^{\text {th }}$-century anthropological thought (KASCHUBA 1999/2004:151-152).
} 
talk about the prikulics (werewolf) because it was the time of the prikulics walk and he was afraid that it would have consequences if we talked about it.

He tried to assert his knowledge the way his parents did. But only until the world changed unexpectedly and he moved from the farmstead to the village, and there he lived forlorn because his knowledge was no longer needed. At his workplace in a factory of 12,000 workers, his coworkers that loved tales would gather around him during lunch break, and his children also liked to listen to him when they were preschoolers. After that, however, he only clung to me, the researcher. And I to him. When I started collecting, he thought I wanted to live by the same principles he did. When, as a young man, I asked him about the magic of intimate life, he misread my inquiry and gave me advice. Later, when I graduated university and was a teacher, he talked to me about his faith and the tragedy of his life, the incurable illness of his youngest child. It was him asking for my opinion, my advice.

I wrote a study on the genealogical and autobiographical function of his belief repertoire: what incidents of curses, encounters with transcendent beings took place in his family and in his life, among his acquaintances, what magical techniques he knew of, and which of them were used in his family. Then I compared the origin, structure, character, and functions of his knowledge with the belief knowledge of his daughter born in 1958. It became clear that János Kocsis did not have an organized repertoire of stories. The stories were only side by side in my collection. All of his stories featured objects, animals, plants, and persons from his world. And I also had the opportunity to experience that the variations of the story type were truly adapted to the actual speech situation, depending on the functions of the utterance. Due to his age, János Kocsis tied beliefs to places, situations, and persons: his knowledge was narrative in nature. His daughter, on the other hand, rarely positioned her beliefs in an epic structure at the time of the research: her knowledge was practical.

The other conclusion of the study was that the way of life and the natural environment into which his beliefs were organically embedded had changed radically. Due to regular walking and carting, and as a result of animal husbandry, he knew the location of landslides and bushes within a 20-30 $\mathrm{km}^{2}$ area, the streams where mythical creatures lived and worked, the healing plants and small animals, the features, sounds, sights, and scents of nature in summer and winter, in daytime and nighttime. After the collectivization of land, he and his family came into some backyard acreage, and at the same time collectivization radically changed the natural environment: because of chemicals, animals and plants had disappeared, lands had been drained and terraced, parcels plowed together, entire tracts had been converted to monoculture. Subsequently, and because of the modernization of transportation (speed, closed passenger cabins), nature has ceased to be familiar and a source of adventure. In his milieu, school enrollment had become mandatory, and listening to the radio, watching television, or going to a cinema became everyday activities. Living on the farmstead, at the road junction, and walking $10 \mathrm{~km}$ each way a day, he was regularly informed about routine and special events by the residents of some ten villages that walked by, carted by, or waited for the bus - whereas living in the village, he was isolated. ${ }^{11}$ The

${ }^{11}$ János Kocsis (1932-2005) is the main character of two studies and one volume: KesZEG 1991, 2003, 2003a, 2012. After his death, I commemorated him in an obituary: Keszeg 2006. 
story of my conversations with him also indicated the fate of the narrative culture and the narrator. Respectively, how the world revealed in the stories had disappeared or changed, how the stories lost their external reference, their guidance function.

\section{CONCLUSIONS: ANOMALIES AND CONTEXTS}

Thomas Kuhn calls it an anomaly when research results do not reflect the observed reality. The long-term persistence of an anomaly results in a scientific and research crisis, a failure of problem solving. The crisis is solved by changing the approach and methods of research (KUHN 2000:63-99). The same situation is described in social psychology with the notion of cognitive dissonance: in this case, it is not science and the outside world that are contradictory, but the value system that one possesses and the one that is prevalent in life (FEstinger 1957). Stories can reflect such dissonance, while at the same time cognitive dissonance affects the status and assessment of stories. Cognitive dissonance is one of the reasons for changes in stories and their popularity. During the long conversations, I managed to understand why the anticipation of science and religion that belief can be eliminated from the interpretation of the world is unfounded. And also that going beyond text- and type-centered research and studying conversation itself can explain radical changes and the consequences of these changes.

The nature of speakers has changed: on the one hand, they have become less trusting of strangers, and on the other, due to increased isolation, it is easier to get them to talk. Belief narratives are related to the intimate, private world of the individual and the community, and, consequently, they are regulated by various moral rules and individual decisions. Due to collectivization and compulsory education and career choices departing from the family model, intergenerational relationships deteriorated, clan memory weakened, and the role of local culture decreased. The acquisition of knowledge in schools and the consumption of media have devalued the transmission of tradition. In order to preserve tradition, the repertoire to be transmitted had to be selected, edited, and fixed. The natural landscape, the physical world upon which the belief system was built and which it interpreted and maintained has changed. Health care, the interpretation and maintenance of interpersonal relations, and the interpretation of natural phenomena were transferred into the care of various institutions. Man himself, his way of life, his lifestyle has changed radically. The function of talking about belief has changed: to some extent, it still shapes the world, but it also represents curiosities to the same extent.

\section{POSITION-ORIENTED SPEECH SITUATION: CASUAL CONVERSATION}

As I recall, it wasn't Thomas Kuhn who made me recognize that research should avoid producing and reinforcing anomalies. Reading his book, I just realized that I myself had been actually refraining from doing so.

For decades, I've spent 45 minutes, twice a day, in the company of strangers. Young and old, men and women, schoolchildren, university students, teachers, clerks, laborers, Romanians and Hungarians, in a casual setting, in an alternating succession. They all had 
one common intention: to get to the county seat, then get home from there. For them, the journey between these two points was a non-lieu. In contrast to tourism, travel was not a goal but a compulsion that they just wanted to be over. While traveling, they became decontextualized: they suspended their names, their roles, their status. ${ }^{12}$ They usually did not know each other and did not count on knowing each other, they did not want to make acquaintance, that is, to embed themselves into each other's social network. In spite of this, even in this particular situation, they initiated a conversation and to some extent everyone got involved in it.

The previously mentioned communities of speakers are made up of persons who live in the same world, know the code of communication, the script of interaction, they solve situations through conversation, exchange or process information. For this to work, they either need to know or get to know the underlying world that the conversation evokes, the domains of implied meaning asserted in the conversation, or to have the intention to consider and assert the consensus that emerges in the conversation.

However, this situation is different, and therefore the relevant question is: can people who do not know each other carry on a conversation, and if so, what about? According to Bakhtin: about the most common, stable, and constant elements of life and the world, things that are evident and common even to strangers. For example - while waiting at the bus stop - about the weather. ${ }^{13}$

\section{SPEECH EVENTS, SPEECH TOPICS: EXAMPLES}

No matter how much I try, I can't name a topic that I hadn't heard of while traveling.

October 1, 2008 was a foggy, cold day with some autumn rain, a time when one gladly clutches onto any friendly words. Perhaps the driver felt this when he stopped. Two of us got on, the bus took off. We were on the outskirts of Cluj when our travel companion cried out. It was a 61-year-old woman, from a village near Torda. She retired from an urban workplace. Her children had left the house. For years, her life and surroundings had been filled with serenity that she could only imagine before. She just came from the hospital where she had been diagnosed with cancer that day. A malignant tumor, as they say. What can one say to a newly condemned stranger? That everyone faces the same fate, that one must enjoy the remaining time, and that maybe there is a god. The young driver was also well-meaning when he admitted to being ill.

June 20, 2013. The taxi was delivering merchandise from Torda to florists in Cluj. The driver was around 50 years old, previously a factory worker in Cluj.

He burst out in a pathetic cry around the lakes of Pusztaszentmárton. How beautiful our country is, how many treasures it holds: forests, oil, salt, thermal waters, mountains, sea! And all this had been squandered. He had worked for an Italian entrepreneur for four years. He said that Romania did not appreciate its God-given resources. Italians would grow tomatoes even on a rock. We buy potatoes from Poland, flowers from the

\footnotetext{
${ }^{12}$ Contextualized individual is a term in French sociology: Boudon 1979. Meaning: an individual's acts in social interactions are based on his/her social role.

${ }^{13}$ BAKHTIN 1985:22.
} 
Netherlands, crops from Turkey. Incompetence and corruption led to this. Politicians have accepted that Romania should be Europe's marketplace.

January 12, 2017. The service car of the MedCenter Laboratory stopped in Cluj, I was the only one that got on. The driver was approaching 40. He was on a phone call, I was leafing through a book. Once we passed the Felek, we were both "freed up". The radio helped. There had been a mild snowfall the day before. In the interactive program, a caller from Szatmár said jokingly that it was the first time in years it had snowed in the city. He asked the authorities not to touch the half-centimeter snow in the streets. They just wanted to enjoy seeing snow again.

The driver started off apropos of this. He brought up the contradiction of the meteorological situation in recent days. South-eastern Romania is struggling with the consequences of abundant snowfall, while in Transylvania we desire more snow. He had "friends" in snow removal. They were performing a week-long emergency service around the Borgo Pass, which paid better. They were happy when the snow fell. They waited it out in a cafe until there was a traffic jam because of the heavy snowfall, then they would go out on the road. The stalled trucks had to deliver goods on time. The drivers hung onto the emergency rescue team like a lifeline, and were willing to make a financial sacrifice. And so, the "friends" would also collect a thank-you-fee worth 2-3 salaries during the emergency week. Besides the increased pay.

September 20, 2007. I had been picked up by a 40-something man in his semi-truck. On the road to Torda, he turned onto a side street, looking for two of his colleagues. The courtyard was paved with granite stone, which had become trendy on the streets of the city, and the corporate directors got their share of the "leftovers". He started off with "We're finalizing the boss' house", and launched into a register of personal experiences of managerial abuse. He grew up in Serbia and moved to Cluj in hopes of a better life. He started a family, learned the Romanian language, the Romanian laws. He still makes mistakes in speaking, yet to this day he feels entitled to judging the laws from the outside. On December 16-17, 1999, he delivered 280 Christmas trees to Bucharest on behalf of the Forestry Commission, to senior staff members. The name of the recipient was on every seedling. And next to it, cheese and brandy. A gift from the company. He wanted to enroll his school-age child at a central school in Cluj. With enrollment completed, the principal had summoned him days later: they did not meet the enrollment requirements. The case fits into a new situation in which central schools choose the children with the most favorable family background because of oversubscription. The family thought it better to move the child back to the neighborhood school and hired a private English teacher. This way he is investing his money into the child's progress, instead of supporting the school.

May 6, 2015. There are three of us in the car. The 55-year-old man had taken his father to the hospital. They had to prepare him for surgery. He put the cash bribe into the Chief's pocket upon admitting the patient. The doctor found an opportunity to warn him: the amount should be doubled, and the other half should be placed in an envelope in his closet, among his clothes.

September 25, 2011. I was lost in thought, didn't notice the beginning of the conversation. Descending from the Felek, the woman sitting on the passenger seat said for some reason that she had been praying to God since she was a little girl that she 
would not be lecherous and a drunkard. From there, their conversation took off, which they continued without acknowledging my presence on the back seat. The driver was a man between 50 and 60 , the passenger a woman of 63 years.

"And you never cheated on your husband?" he asked calmly, without the apparent intent of prying.

No, even though there had been plenty of opportunities during field trips. It was her principle throughout her life that everyone would pay for their sins.

"Anything that brings joy, anything that man does out of love, is not a sin", the man remarked (still calmly).

The woman continued: her husband had often been unfaithful to her. He cheated on her with their neighbor. He went to her at two in the morning, and when he returned, he said he just had a glass of wine with the neighbor. "He has to account for it", she concluded the story. And death came for him early. He died of alcohol poisoning at the age of 56 .

We were at the lakes of Pusztaszentmárton, traffic cops on the side of the road. "They're hunting for money", they both stated. The woman recounted a cop story. A cop had once unjustly imposed a fine on her husband. He cursed him to his face: may you spend the money on medicine, and all four wheels of your vehicle be slashed. Half a year later they met again. "Do you recognize me?" the policeman asked. He admitted that following the curse, he had found his baby in a $42^{\circ} \mathrm{C}$ fever, and the next morning all four wheels of his car had been slashed. He left the police service then.

May 28, 2016. Four of us were sitting in the car. The driver was around 40 years old, the passenger next to him around 65. He picked him up in Nagyenyed, they were distant acquaintances. They were in the middle of the conversation. The passenger talked about a wedding, that whether one wanted to or not, one had to attend if one wanted the favor returned. Those who had been invited had to give a definite response. Rejecting the invitation is better for the family of the young couple than accepting and not showing up. The driver chimed in. There was a wedding taking place today, and they had also accepted the invitation. However, his father had died suddenly and the memorial service (părăstas) was to be held tomorrow. However, 16 people would have missed the wedding because of it. He therefore requested permission from the priest to hold the memorial service earlier. In fact, the părăstas should be held on the $40^{\text {th }}$ day after death. It is very important, because until then, the soul of the deceased roams the earth (bântuie), and the părăstas facilitates his release into the afterlife (dezlegare). The priest said that in such a case, the memorial service can be held a few days earlier. It is better to hold it earlier rather than after the 40 days. Holding the ceremony beyond the 40 days would hurt the departed soul. And since they held the memorial service as they had been advised, they were able to attend today's wedding. They will attend the wedding ceremony in the black mourning suit (doliu negru) and stay only until the newlywed coin dance, after which they will take their leave. The man sitting next to me showed keen interest, seeing that his family was also preparing for a memorial service. 


\section{CONCLUSIONS: THE REPRESENTATION OF SELF IN CONVERSATION}

For the speakers in the above speech situations, the speech situation allows both listening and speaking. If they choose to speak, they decide for themselves what their contribution to the conversation will be: initiate, perhaps guide the conversation, express emotion, communicate information, take a position. In the conversations chosen as examples, the same basic situation is repeated: each participant in the conversation is a traveler and a stranger. The speakers do not have to clarify their identity, they do not have to identify the external reference behind the narrative reality, the utterances have no consequences beyond the speech situation. In this case, conversation is decontextualization. It contextualizes neither the individuals nor what has been said.

If at all possible, I try not to participate in such conversations. However, whether I want it or not, I am involved in the speech situation, and my travel companions count on this: I am a hearer, or more precisely, because I am not the addressee of the conversation, I am an overhearer. ${ }^{14}$

In this case, the researcher as overhearer sets a different but no less important research priority. He follows the conversational willingness and strategies of a mobile society. In this particular context, the techniques of social distances and sympathies, the assertion and bridging of distances, and the strategies of guiding conversations are revealed. Improvised conversations allow us to follow individuals' perceptions of the topicality of everyday life, the discursive forms of representing these topicalities, and the emotional responses and logic of reasoning mobilized by the topicalities. The question is, what all can be brought up between two unfamiliar people, that is, where are the boundaries and bridges between two people in the conversational situation?

In the interpretation of this speech situation, instead of Dell Hymes, Erving Goffman, a practitioner of ethnomethodology, should be mentioned. When Goffman decided to focus on the individual and examine individual performance, he narrowed the framework of studying communication. His starting point was the idea that an individual's communication is social in nature: it contributes to the functioning of society, while at the same time its direct purpose is acceptance and inclusion in the social network. Therefore, his/her behavior follows not a script but a strategy. ${ }^{15}$ The peculiarity of this concept is that it approaches the individual from a theatrical perspective; accordingly, communication is based on dramaturgical principles. Day-to-day life is a stage where the self "performs" itself, guiding and controlling the impressions that others might form about it. Its purpose is self-representation and impression management (GoFFMAN 1999:11).

If one follows sociolinguistic research that interplays with the philosophy of language, sociology, and linguistics, one would be interested in "how we coordinate our behavior during conversation, how we influence each other, control, flatter, comply in the framework of conversation and through it" (РцÉH 2012:8). The rules of self-assertion

\footnotetext{
${ }^{14}$ Speech acts may have a fourth participant besides the speaker, the addressee, and the hearer - the overhearer. If the speaker counts on the existence of the overhearer, the latter is a known overhearer. If the speaker does not know the overhearer or is not aware of his/her presence, the overhearer is an unknown overhearer (CLARK - CARLSON 1997:135).

${ }^{15}$ The interpretation of E. Goffman's method: WINKIN 2001:109-125.
} 
and coexistence can be distinguished in these analyses, as conversation extends into the field of intimacy, as if "into a game of power", asserting "hidden human factors" and "unspoken, tacit regularities" (PLÉH 2012:8-12).

If one follows the performance of conversation, one can distinguish the organization of the text and the rules of language use; and if the act of conversation, the social relations and hierarchies (PLÉH 2012:12). As a text, conversation has a form, a genre; as a discourse, it has actors and a presentation medium (РеÉH 2012:24-33). Issues that arise include the rules of turn-taking and form of address as an "alignment system"; conversation strategies and the arrangement of utterances; gestures of courtesy; the assertion and stereotypes of gender differences; tensions and disorders in the conversation.

It is always adults who are unfamiliar with each other that are involved in the abovementioned conversation situations. According to our observation, young people under 25-30 years of age, and especially young women, do not initiate such conversations. Participation in a conversation is voluntary. The fact that someone usually breaks the silence during the trip and initiates an utterance proves that people have the compulsion or desire to talk. What all does everyday conversation serve? In general, it can be said to reflect and address the philosophy, attitude, and mood of day-to-day life. Speakers are eager to catch up on topics trending in the media. Media news engage the attention for a couple of days, integrating into everyday discourse, introducing public figures, ideas, and logic of reasoning into the discourse. People are happy to repeat journalists' opinions, but they are just as happy to dispute them. It is common to use political awareness and to exemplify the incompetence and corruption of the national and local political elites, but without embedding it in the context of a party ideology. Another recurring topic is personal experiences in various institutions. Dominant among them are hospital experiences, followed by courtroom and tax office experiences. What usually gets voiced are grievances, humiliation by the institution, and disregard. Speakers are also happy to share their memories. Guest-working abroad, a successful enterprise, the success of one's children, or an illness in the family are recounted without any censorship.

Daily conversation is beneficial and pragmatic in many ways. It provides the opportunity to talk, express oneself, voice an opinion - in general, the opportunity for self-assertion, self-representation, and narrative embedding. During everyday conversation, speakers often find vindication of the grievances they had suffered. The conversation has a positive influence: there is usually no disputing, the participants of the conversation are eagerly following the performance, and they reinforce the speaker with their corresponding experiences. Everyday conversation allows one to exercise and assert one's identity, to navigate the social arena and the cognitive sphere, and to connect the private world, the world of someone else, and the world at large. Conversation endows "today" with content and communication events. ${ }^{16}$

16 "Today" as a form of consciousness and a ritual: Keszeg 2003b. 


\section{REFERENCES CITED}

BAKhtin, Mikhail M.

1985 The Word in Life and in Poetry (Basic Questions of Socio-poetics). In BAKHTIN, Mikhail M.: The Word in Life and in Poetry. Budapest: Európa Könyvkiadó. 5-54. (Orig. pub.: 1975).

Boudon, Raymond

1990 La logique du social [The Logic of the Social Action]. Paris: Hachette Littératures.

Clark, Herbert H. - CARlson, Thomas B.

1997 Beszédaktusok és hallgatók [Hearers and Speech Acts]. In PléH, Csaba SiKLAKI, István - Terestyéni, Tamás (eds.) Nyelv-Kommunikáció-Cselekvés, 123-166. Budapest: Osiris Kiadó. (Orig. pub.: 1982).

DöмÖTÖR, Tekla

1981 A magyar nép hiedelmvilága [Hungarian Folk Beliefs]. Budapest: Corvina.

FEJös, Zoltán

1985 Hiedelemrendszer, szöveg, közösség. Esettanulmány Karancskeszi példáján [Belief System, Text, Community. A Case Study of Karancskeszi]. I-II. Néprajzi Közlemények XXVII-XXVIII.

FESTINGER, Leon

1957 A Theory of Cognitive Dissonance. Stanford: Stanford University Press.

GoFFMAN, Erving

1999 Az én bemutatása a mindennapi életben [The Presentation of Self in Everyday Life]. Budapest: Pólya.

Granovetter, Mark

1994 A gazdasági intézmények társadalmi megformálása: a beágyazottság problémája [The Social Formation of Economic Institutions: The Problem of Embeddedness]. In: Lengyel, György - SzÁnTó, Zoltán (eds.): A gazdasági élet szociológiája, 61-78. Budapest: BKE.

GricE, H. Paul

1997 A társalgás logikája [The Logic of Conversation]. In: PléH, Csaba - SikLaKi, István - TerestyénI, Tamás (eds.): Nyelv - Kommunikáció - Cselekvés, 213227. Budapest: Osiris Kiadó. (Orig. pub.: 1975)

GrIFFIN, Em

2001 Bevezetés a kommunikációelméletbe [Introduction to Communication Theory].

Budapest: Harmat. (Orig. pub.: 1991)

KaschuBA, Wolfgang

2004 Bevezetés az európai etnológiába [Introduction to European Ethnology]. (Antropos.) Debrecen: Csokonai Kiadó. (Orig. pub.: 1999. Rev. ed.: 2003)

Keszeg, Vilmos

1991 A hiedelemtudás szerkezete [The Structure of Belief]. Erdélyi Múzeum 53:1$4,122-144$.

1993 A tartalom szerveződése a beszédszokásokban [Content Organization in Speech Habits]. Korunk 3(4):8, 23-31. 
2002 Egy látomás. Az esemény, a reprezentáció és az ítélkezés [A Vision. Event, Representation, Judgment]. In: Keszeg, Vilmos: Homo narrans. Emberek, történetek és kontextusok, 28-59. Cluj-Napoca: KOMP-PRESS.

2003 Tájban élö ember: hiedelem és biográfia [Man in the Landscape: Belief and Biography]. In: Viga, Gyula (ed.): Vándorutak - Múzeumi örökség. Tanulmányok Bodó Sándor tiszteletére, 60. születésnapja alkalmából, 133150. Budapest: Archaeolingua.

2003a L'intégration des superstitions dans les structures cognitives [The Integration of Superstitions in Cognitive Structures]. Acta Ethnographica Hungarica 448(3-4):397-420.

2003b A mai nap mint rítus és mítosz [Today as Ritual and Myth]. Tabula 6(2):187215.

2006 Nekrológok [Obituaries]. Székelyföld X(7):105-113.

2012 Történetek és történetmondás Detrehemtelepen [Stories and Storytelling in Detrehemtelep]. Kolozsvár: Erdélyi Múzem-Egyesület. (Emberek és kontextusok 6.)

KuHN, Thomas S.

2000 A tudományos forradalmak szerkezete [The Structure of Scientific Revolutions]. Budapest: Osiris. (Orig. pub.: 1970).

MalinowsKi, Bronislaw

1948 Magic, Science and Religion. In Magic, Science and Religion and Other Essays (Selected, and with an Introduction by Robert Redfield), 17-92. Glencoe, Illinois: The Free Press. (Orig. pub. 1925).

PléH, Csaba

2012 A társalgás pszichológiája [The Psychology of Conversation]. Budapest: Libri.

Pócs, Éva

1981 Zagyvarékas néphite [Folk Beliefs in Zagyvarékas]. Néprajzi Közlemények IX(3-4).

Voigt, Vilmos

1978 Epikus törvények [Epic Laws]. In KIRÁLy, István (EIC) Világirodalmi Lexikon II. Cam-E, 1165-1166. Budapest: Akadémiai Kiadó.

Winkin, Yves

2001 Anthropologie de la communication. De la théorie au terrain [The Anthropology of Communication. From Theory to the Field]. Bruxelles-Paris: De Boeck-Larcier S. A. 
Vilmos Keszeg is Professor at the Department of Hungarian Ethnography and Anthropology, Babeş-Bolyai University, Cluj-Napoca, Romania, heading the Doctoral School of Hungarology Studies. A specialist of folk beliefs, popular literacy, and narration, he has carried out ethnographic fieldwork in almost all parts of Transylvania and Moldova inhabited by Hungarians. His main publications include, among others Mezőségi hiedelmek [Folk Beliefs of the Mezőség Region] (1999); Homo narrans. Emberek, történetek és kontextusok [Homo Narrans. People, Stories, and Contexts] (2002); Alfabetizáció, írásszokások, populáris írásbeliség [Alphabetization, Writing Habits, Popular Literacy] (2008); A történetmondás antropológiája: Egyetemi jegyzet [The Anthropology of Narration] (2011). E-mail: vkeszegv@gmail.com 